\begin{tabular}{|l|l|}
\hline 2. To: (Receiving Organization) & 3. From: Coriginating Organization) \\
SST Retrieval Engineering & SST Retrieval Engineering \\
\hline 5. Proj./Prog./Dept./Div.: & 6. Design Authority/ Design Agent/Cog. \\
W-320 & J.W. W. Bailey /J. R. Bellomy
\end{tabular}

8. Originator Remarks:

Supporting Document Approval and Initial Release
11. Receiver Remarks: 11A. Design Baseline Document? [X] Yes [] No

4. Related EDT No.:

610566

7. Purchase Order No.:

$N / A$

9. Equip./Component No.: AY Farm

10. System/Bldg./Fac il ity: 241-AY-102

12. Major Assm. Dwg. No.: $\mathrm{H}-2-818708$, sht 1 $\mathrm{H}-2-818708$, sht 2

13. Permit/Permit Application No.: $N / A$

14. Required Response Date: $N / A$

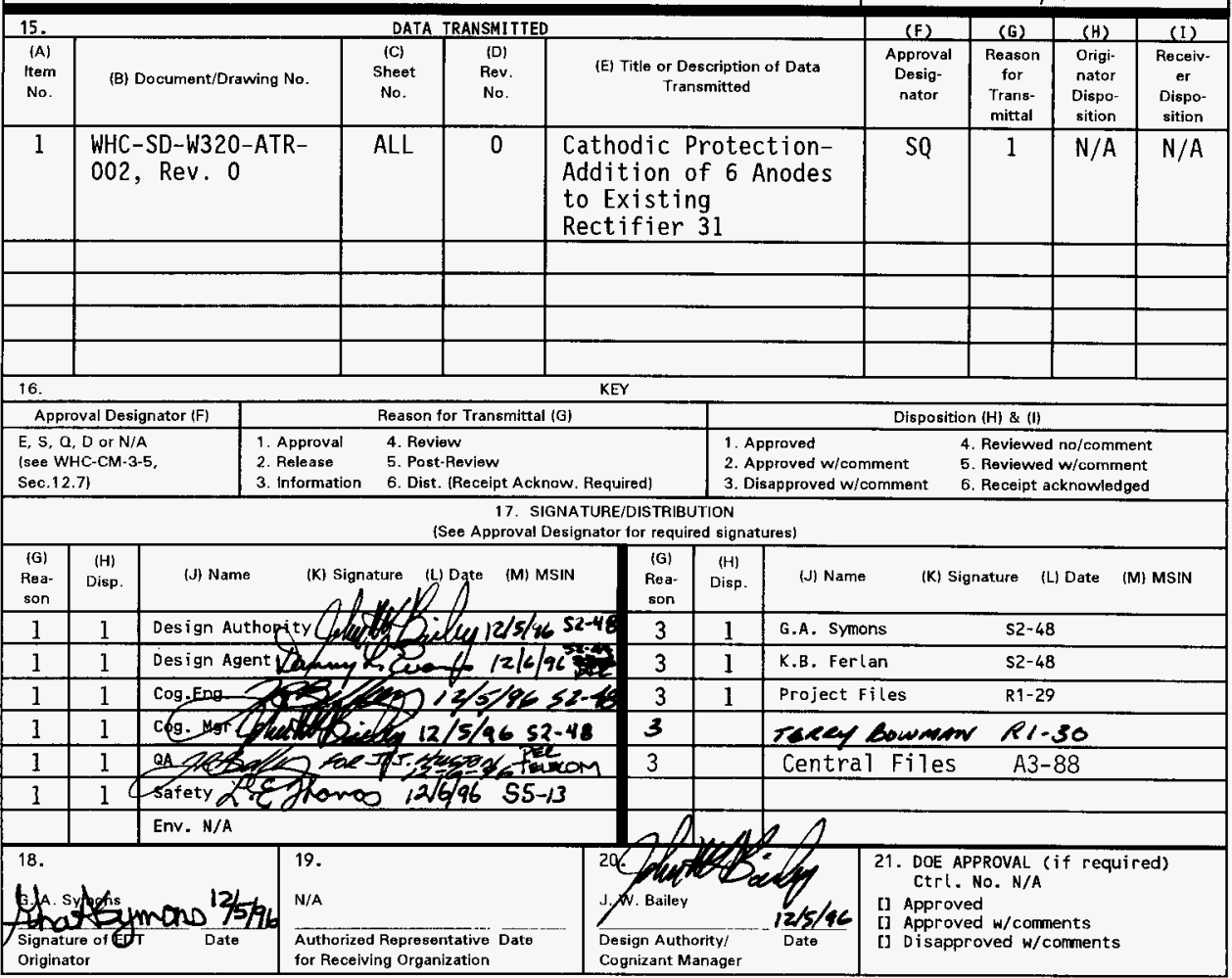




\section{Cathodic Protection- Addition of 6 Anodes to Existing Rectifier 31}

\section{Gina A. Symons}

SGN Eurisys Services Corporation (SESC), Richland, WA 99352

U.S. Department of Energy Contract DE-AC06-87RL10930

\begin{tabular}{|c|c|c|}
\hline $\begin{array}{l}\text { EDT/ECN: } \\
\text { Org Code: } \\
\text { B\&R Code: }\end{array}$ & $\begin{array}{l}610566 \\
08 E 00 \\
\text { EW3130010 }\end{array}$ & $\begin{array}{l}\text { UC: } 510 \\
\text { Charge Code: } \\
\text { Total Pages: }\end{array}$ \\
\hline
\end{tabular}

Key Words: Project $W-320$, cathodic protection, rectifier 31

Abstract: Acceptance test report for Cathodic Protection - Addition of 6 Anodes to existing Rectifier 31 for Project $W-320$

TRADEMARK DISCLAIMER. Reference herein to any specific commercial product, process, or service by trade name, trademark, manufacturer, or otherwise, does not necessarily constitute or imply $i$ ts endorsement, recommendation, or favoring by the United States Government or any agency thereof or its contractors or subcontractors.

Printed in the United States of America. To obtain copies of this document, contact: WHC/BCS Document Control Services, P.0. Box 1970, Mailstop H6-08, Richland WA 99352, Phone (509) 372-2420; Fax (509) 376-4989.
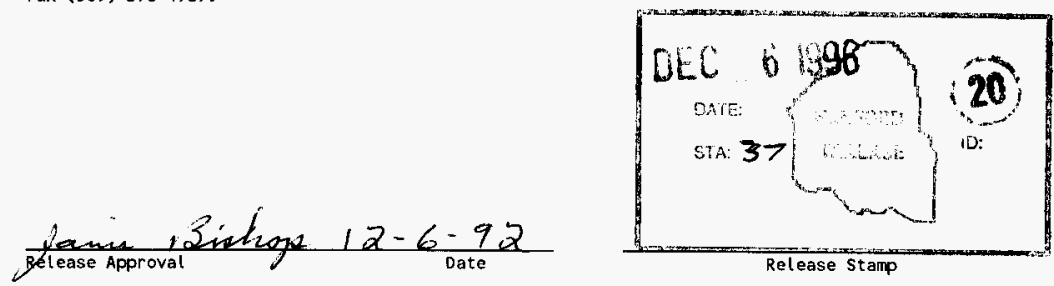

\section{Approved for Public Release}




\section{GS 12/5/96}

ACCEPTANCE TEST PROCEDURE WHC-SD-W320-ATR-002

TEST TITLE Cathodic Protection - Addition of (6) Anodes to Existing Rectifier 31

LOCATION West side of 241-AY Tank Farm outside of west fence

PROJECT NUMBER $W-320$

WORK ORDER ER4319

PROJECT TITLE Tank 241-C-106 Sluicing

Prepared By

ICF Kaiser Hanford Company

Richl and, Washington

For the U.S. Department of Energy

Contract DE-ACO6-93RL12359

PROCEDURE APPROVAL

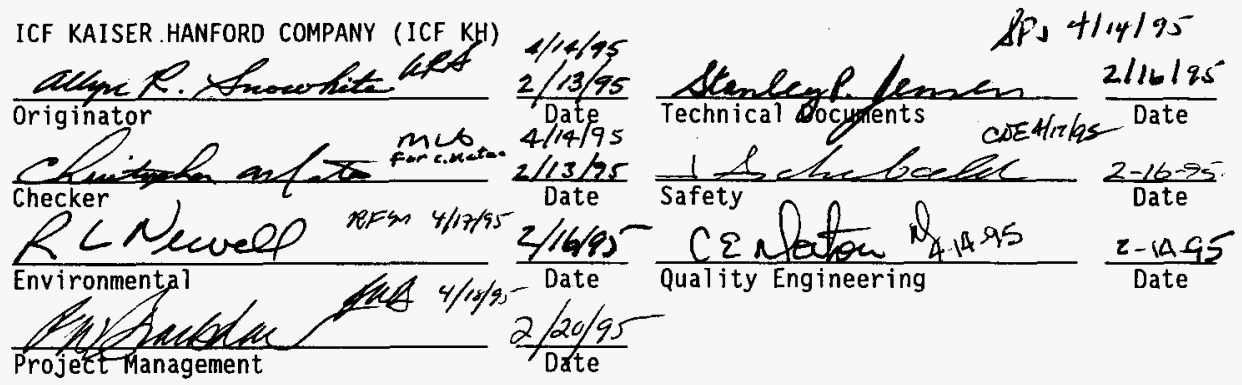

Westinghouse Hanford Company (WHC)

QLelenan Zan-

Projects Deparkment

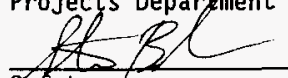

Safety
(1)
- $\frac{4 / 10 / 52}{\text { Date }}$

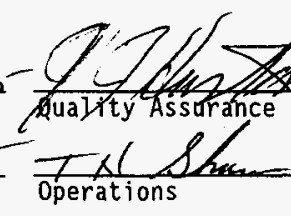

$\frac{4+8-\operatorname{sis}}{\text { Date }}$ $\frac{4-19-95}{\text { Date }}$ 
EXECUTED BY

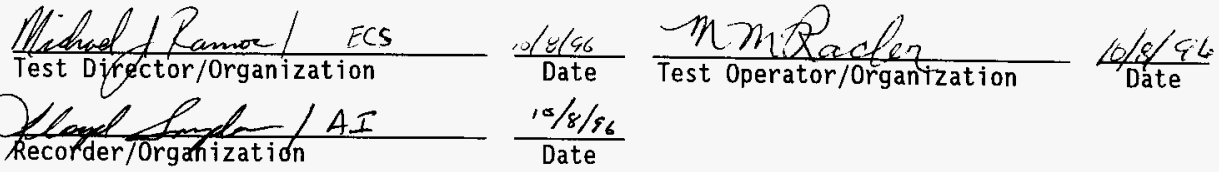

WITNESSES

$\frac{M \cdot A}{\text { Witness/Organization }}$

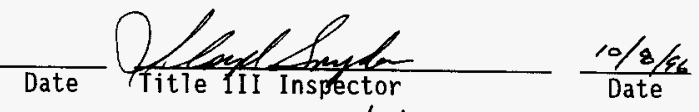

$\frac{N, A}{\text { Witness/Organization }}$

Date Witness/0rganization

Date

\section{A-E APPROVAL}

ICF Kaiser Hanford Company (ICF KH)

Without

exceptions X

With exceptions

With exceptions

resolved outstanding

Konl f. Fermen

Afceptance, inspection

project Managen

$\frac{10 / 11 / 96}{\text { Date }} \frac{\text { Joflearente for G.C.McDovald } 10 / 15 / 96}{\text { Date }}$ $10 / 41 / 96$

Date

TEST APPROVAL AND ACCEPTANCE

Westinghouse Hanford Company (WHC)

Without

exceptions
With exceptions resolved
With exceptions outstanding

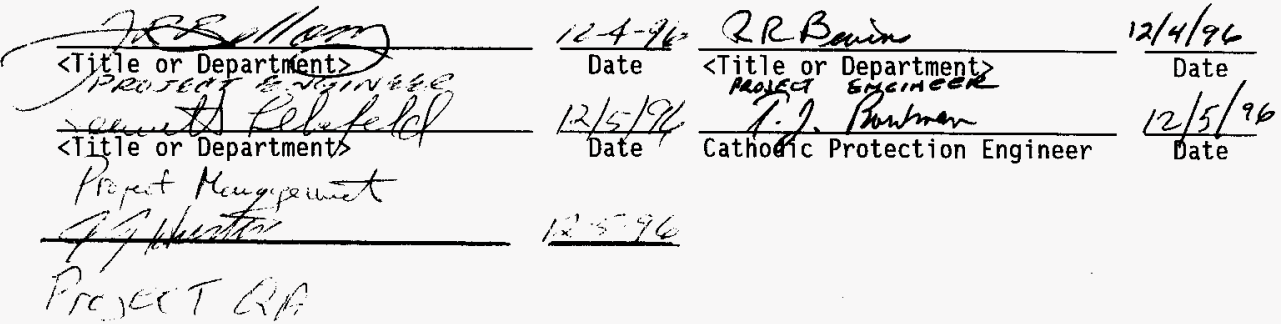


Section

TITLE/PROCEDURE APPROVAL

EXECUTION AND TEST APPROVAL

TABLE OF CONTENTS

1 PURPOSE

4

2

REFERENCES

4

RESPONSIBILITIES

4

CHANGE CONTROL

EXECUTION

EXCEPTIONS

PREREQUISITES, EQUIPMENT/INSTRUMENTS, AND ABBREVIATIONS

PIPE TEST CONDUCTORS, NATIVE POTENTIALS, ANODES, AND SYSTEM OPERATION

NOTE: At completion of test, enter pages added during performance of test to this Table of Contents. 
This Acceptance Test Procedure (ATP) has been prepared to demonstrate that the cathodic protection system additions are installed, connected, and function as required by project criteria.

\section{REFERENCES}

2.1 DRAWINGS

H-2-818708, Sh 1, Rev 0 Electrical - Cathodic Protection P1an \#3

H-2-818708, Sh 2, Rev 0 Electrical - Cathodic Protection Details

2.2 SPECIFICATIONS

W-320-C7, Rev $0 \quad$ Construction Specification (Section 16640)

2.3 ENGINEERING CHANGE NOTICES (ECN)

Prior to fina1 test approval, enter ECNs written against this ATP.

3 RESPONSIBILITIES

3.1 GENERAL

Each company or organization participating in this ATP will designate personnel to assume the responsibilities and duties as defined herein for their respective roles. The designees shall become familiar with this ATP and the systems involved to the extent that they can perform their assigned duties.

3.2 WHC PROJECT ENGINEER

3.2.1 Designates a Test Director.

3.2.2 Coordinates testing with the Facility Manager.

3.2.3 Acts as liaison between the participants in acceptance testing.

3.2.4 Distributes the approved testing schedule before start of testing.

3.2.5 Schedules and conducts a pretest kickoff meeting with test participants when necessary.

3.2.6 Notifies the persons performing and witnessing the test 2 days before the start of testing.

3.2.7 Schedules a dry run when necessary.

3.2.8 Notifies concerned parties when a change is made in the testing schedule.

3.2.9 Signs Execution and Test Approval page when test is approved and accepted. 
3.2.10 Takes necessary action to clear exceptions to the test.

3.2.11 Signs Exception Form when exception has been resolved.

3.2.12 Provides a distribution 1ist for the approved and accepted ATP(ATR).

\subsection{TEST DIRECTOR}

3.3.1 Coordinates and directs acceptance testing.

3.3.2 Confirms that field testing and inspection of the system or portion of the system to be tested has been completed.

3.3.3 Stops any test which, in his or her judgment, may cause damage to the system until the problem has been resolved.

3.3.4 After verifying there is no adverse impact, may alter the sequence in which systems or subsystems are tested.

3.3.5 Ensures that required environmental conditions are maintained.

3.3.6 If a test is to be suspended for a period of time, ensures that the system is left in a safe mode.

3.3.7 Before restarting suspended test, reverifies the test prerequisites.

3.3.8 Initiates ECNs to document required changes to the ATP.

3.3.9 Reviews recorded data, discrepancies, and exceptions.

3.3.10 Obtains information or changes necessary to clear or resolve objections during the performance of the test.

3.3.11 Signs Execution and Test Approval page when test has been performed.

3.3.12 Signs Exception Form when exception has been resolved.

3.3.13 Obtains required signatures on the ATP Master prior to reproduction and distribution.

3.4 WITNESSES (Provided by Participating Organizations. One witness shall be a Title III acceptance inspector.)

3.4.1 Witness the tests.

3.4.2 Review results of testing.

3.4.3 Assist the Test Director when requested.

3.4.4 Sign Execution and Test Approval page when test has been performed.

3.4.5 Sign Exception Form when exception has been resolved. 
3.5 RECORDER (Provided by ICF KH)

3.5.1 Prepares a Field copy from the ATP Master.

3.5.2 Records names of all designated personnel on Field copy of ATP prior to start of testing.

3.5.3 Records test instrument identification numbers and calibration expiration dates.

3.5.4 Initials and dates every test step on the Field copy as it is completed next to the step number or on a data sheet, when provided. Records test data. On data sheets where there is not room for both the initial and date, date may be entered at bottom of column.

3.5.5 Records objections and exceptions on an Exception form. Uses additional Exception forms as needed. Notifies the Test Director at time the objection is made.

3.5.6 Signs Execution and Test Approval page when test has been performed.

3.5.7 After test is finished, assigns alpha numeric page numbers to added data sheets and Exception forms. Records page numbers in the Table of Contents.

3.5.8 Transfers Field copy entries for each step to the Master in ink or type, signs, and dates. Transmits the completed Master to the Test Director for approval signature routing. Transmits the Field copy to Construction Document Control for inclusion in the official project file.

3.5.9 Signs Exception Form when exception has been resolved and transmits to Test Director.

3.6 TEST OPERATOR

3.6.1 Performs test under direction of the Test Director.

3.6.2 Provides labor, equipment, and test instruments required for performing tests which have not been designated as being provided by others.

3.6.3 Requests in writing from the Test Director those services, materials, or equipment that have been designated as being supplied by others.

3.6.4 Confirms that all equipment required for performing test will be available at the start of testing.

3.6.5 Signs the Execution and Test Approval page.

3.7 DESIGN ENGINEER ACCEPTANCE INSPECTION

3.7.1 Evaluate results.

3.7.2 Sign for A-E Approval on Execution and Test Approval page.

GAS $12 / 5 / 96$

W320002.ATP. 2323

$-6-$

WHC-SD-W320-ATR-002 
Required changes to this ATP must be processed on ECNs in accordance with company procedures. If a need for change is discovered in the course of running the test, the test shall be stopped until the ECN is approved. However, this does not prevent the running of another portion of the test unaffected by the change.

\subsection{OCCUPATIONAL SAFETY AND HEALTH}

Individuals shall carry out their assigned work in a safe manner to protect themselves and others from undue hazards and to prevent damage to property and environment. Facility line managers shall assure the safety of activities within their areas to prevent injury, property damage, or interruption of operation. Performance of test activities shall always include safety and health aspects.

\subsection{PERFORMANCE}

5.2.1 Conduct testing in accordance with ICF KH Procedure CON 3.5 (Performance and Recording of Acceptance Test Procedures).

5.2.2 Perform test following the steps and requirements of this procedure.

\section{EXCEPTIONS}

6.1 GENERAL

Exceptions to the required test results are sequentially numbered and recorded on individual Exception forms. This enables case-by-case resolution and approval of each exception.

Errors/exceptions in the ATP itself shall NOT be processed as test exceptions (see Section 4 CHANGE CONTROL).

\subsection{RECORDING}

6.2.1 Number each exception sequentially as it occurs and record it on an Exception Form (KEH-428), sample appended.

6.2.2 Enter name and organization of objecting party for each exception.

6.2.3 Enter planned action to resolve each exception when such determination is made.

\subsection{RETEST/RESOLUTION}

Record the action taken to resolve each exception. Action taken may not be the same as planned action.

6.3.1 When action taken results in an acceptable retest, sign and date Retest Execution and Acceptance section of the Exception Form.

$$
\text { GAs } 12 / 5196
$$


6.3.2 When action taken does not involve an acceptable retest, strike out the Retest Execution and Acceptance section of the Exception Form.

6.4 APPROVAL AND ACCEPTANCE

WHC provides final approval and acceptance of exceptions by checking one of the following on Exception Form:

6.4.1 Retest Approved and Accepted: Applicable when Retest Execution and Acceptance section is completed.

6.4.2 Exception Accepted-As-Is: Requires detailed explanation.

6.4.3 Other: Requires detailed explanation.

WHC signs and dates the Exception Form and obtains other WHC internal approvals, if required.

\subsection{DISTRIBUTION}

A copy of the approved Exception Form is distributed to each participant. The signed original is attached to the ATP Master.

7 PREREQUISITES, EQUIPMENT/INSTRUMENTS, AND ABBREVIATIONS

\subsection{PREREQUISITES}

The following conditions shall exist at start of testing for that portion of the system being tested.

7.1.1 Buried piping in the 241-AY Tank Farm and the cathodic protection system have been inspected for compliance with construction documents.

7.1.2 Reference documents (including this ATP) have been verified for correct revision number and outstanding ECNs.

7.1.3 A Prejob Safety Analysis has been prepared and a Prejob Safety Meeting has been conducted.

7.1.4 Test instruments (except Waveform Analyzer) have a valid calibration stamp attached. Test instrument jentification numbers and calibration expiration dates have been recorded in Para 7.2.

\subsection{EQUIPMENT/INSTRUMENTS}

Supplied by Test Operator unless otherwise noted. \{Delete items not required. Add any additional necessary items.

7.2.1 Voltohmmeter (VOM): Digital, portable, 0-150 V ac/dc.

Instrument No. 0005 Expiration Date $3 / 28 / 61$ 
7.2.2 Waveform Analyzer: Hand held instrument with display of ON-OFF pipeto-soil potential, DC potential or AC potential, MCMiller $\mathrm{Co}_{\text {, }}$ Mode1 WFA-1.

7.2.3 Test leads with insulated covers for wire clips.

7.2.4 Portable test ree1, containing a minimum of 100 feet of test wire, $600 \mathrm{~V}$, No. 18 AWG minimum.

7.2.5 Portable copper-copper sulphate reference electrode.

7.2.6 Pipe locator.

7.3 ABBREVIATIONS

ECN Engineering Change Notice 
NOTE: The steps shown in Paragraphs 8.1 and 8.2 may be done concurrently.

8.1 The following steps will verify pipe test conductors are (1) terminated on designated terminals in accordance with the Drawings, (2) 1abeled correctly with the pipe number or reference electrode. Record terminal number to which each conductor is connected.

oh $10.1-468.1 .1$ Test Station T(31-204)

4 inch SL-100-M9 w/6 inch ENC-M26a

4 inch SN-200-M9 w/6 inch ENC-M26a

Terminals 1 and 2

4 inch 225\# STM $w / 10^{\prime \prime}$ ENC (unPustaroso)

Terminals 3 and 4

Reference Electrode $\mathrm{NN}_{22} \boldsymbol{\theta}_{5-28-96}$ Terminal 5

Ch $10.1-94$ Test Station T(31-205)

4 inch SL-100-M9 w/6 inch ENC-M26a

Terminals 1 and 2

6 inch PSW - \$505

Terminals 7 and 9

6 inch PSW - S508

Terminals 6 and 8

3 inch $\mathrm{PW}-4513$

Terminals 3 and 4

Reference Electrode

Terminal 5

8.2 Using a VOM, measure and record resistance between a11 conductors that are identified as being connected to the same pipe. Resistance measured shat1 be less than 1 ohm.

Ch $10+16$

8.2.1 Record the following VOM data:

Manufacturer

Mode 1

Serial Number

Calibration Sticker Data

ch 10 -14Ge 8.2 .2 Test Station $T(31-204)$ Eca-244 $\frac{5 \pi}{5-6-96}$

$\frac{\text { Fluke }}{\frac{80243}{0005}} \frac{3-28-97}{}$

4 inch SL-100-M9 w/6 inch ENC-M26a

4 inch SN-200-M9 w/6 inch ENC-M26a

4 inch 225\# STM W/lo" ENC (unpeorerob)

\begin{tabular}{|c|}
\hline .8 \\
\hline .4 \\
\hline .3 \\
\hline
\end{tabular}

$=2 N^{2} 326 \quad \frac{\pi}{5-28-96}$

$G \times 21596$

W320002.ATP. 2323

WHC-SD-W320-ATR-002 


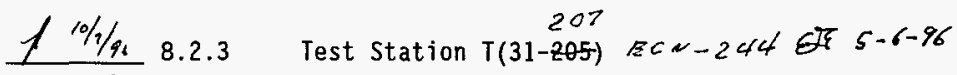

4 inch SL-100-M9 w/6 inch ENC-M26a

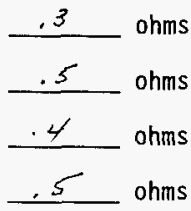

$\frac{110 / 7 / 56}{1^{10 / 4 / 46}} 8.3$

6 inch PSW - S505

.5 ohms

6 inch PSW - S508

3 inch PW-4513 ohms

$110 / 1 / 4$. 8.4.1 $A(31-331)$ Anode Lead Cable

$1 \% / 2 / 16$ 8.4.2 $A(31-332)$ Anode Lead Cable

$\mathscr{L}^{10 / 7 / 56}$ 8.4.3 $\mathrm{A}(31-333)$ Anode Lead Cable

Ito/h/4c 8.4.4 A(31-334) Anode Lead Cable

$110 / 7 / 46$ 8.4.5 A(31-335) Anode Lead Cable

$16 / 7 / 48.4 .6$

A(31-336) Anode Lead Cable

NOTE: Anode ground bed tests (voltage output tests of each anode) will not be required by this ATP since the majority of anodes are existing, and their voltage output would affect the output of the new anodes which would result in erroneous voltage values for the new anodes.

8.5 The following steps will provide the native potential of each new pipe using both the permanent reference electrode and a portable reference electrode for comparison.

NOTE: Connect the pipe test conductor to the positive terminal of the Wave Form Analyzer and the lead from the permanent or portable reference electrode to the common terminal of the Wave Form Analyzer. Turn the mode switch, on the Wave Form Analyzer, to the DC position. (Place the portable reference electrode directly above the pipe for those tests that require the use of the portable reference electrode).

Test Station $T(31-204)$ ECN-2044 \& 5-6-96

Volts

Permanent Reference Electrode and 4-inch $-.673$ SL-100-M9 w/6" ENC-M26a

Portable Reference Electrode and 4-inch SL-100-M9 w/6" ENC-M26a $=.673$

Permanent Reference Electrode and 4-inch SN-200-M9 w/6" ENC-M26a 
Portable Reference Electrode and 4-inch

SN-200-M9 W/6" ENC-M26a

Test Station T(31-205) BटC-244 हो $5-6-96$

Permanent Reference Electrode and 4-inch

SL-100-M9 w/6" ENC-M26a

Portable Reference Electrode and 4-inch

SL-100-M9 w/6 ${ }^{\text {If }}$ ENC-M26a

8.6 The following steps will verify proper operation of the cathodic protection

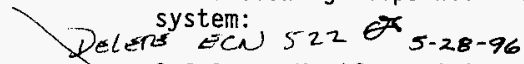

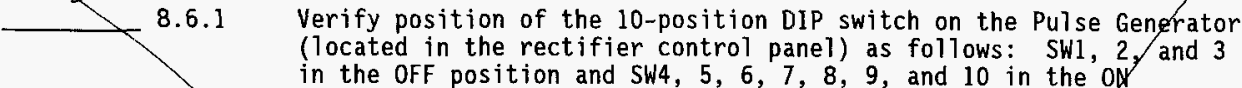
position.

8.6.2

Close Rectifier 31 input circuit breaker and verify the/rectifier has

been energized for 24 hours prior to the following test.

8.6.3 Measure and record the ON and OFF pipe to soil potential of each protected pipe by use of the Waveform Analyzer. OfF values should be equal to or more negative than $(-) 0.85 \mathrm{~V}$ dc (ie, $(-) 0.86 \mathrm{~V} \mathrm{dc}$ ) or the ON values shquld be $100 \mathrm{mV}$ more negative than the OFF vaTues. If these values ake not attainable by use of the permanent reference electrode, a portable reference electrode may be used. For unprotected pipe there is no criteria and the values will be recorded for record purposes.

NOTE: Connect positive termina of the Waveform Analyzer to the reference electrode terminal and the common terminal on the Waveform Analyzer to the pipe test conductor termixal. Turn the Mode switch from the OFF position to the WFA position, record values, then turn to the OFF position.

8.6.3.1 Test Station $\mathrm{T}(31-204)$

Reference Electrode and 4-inch SL-100-M9 w/6-inch ENC-M26a

Reference Electpode and 4-inch SN-200-N9 w/6-inch ENC-M26a

Reference Electrode and 4-inch 225\# STM (Unprotected)

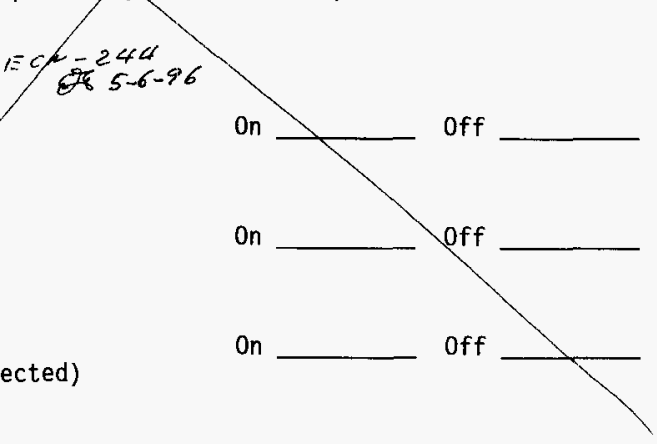


8.6.3.2 Test Station T(31-205) हCw-244 दो 5-6-96

Reference Electrode and

On off

4-inch SL-100-M9

w/6-inch ENC-M26a

Reference ETectrode and

6-inch PSW-S508 (Onprotected)

Reference Electrode and

3-inch PW-4513 (Unprotected)

Reference Electrode and

6-inch PSW-5505 (Unprotected)

8.7 Festing complete, secure from test.

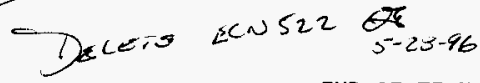

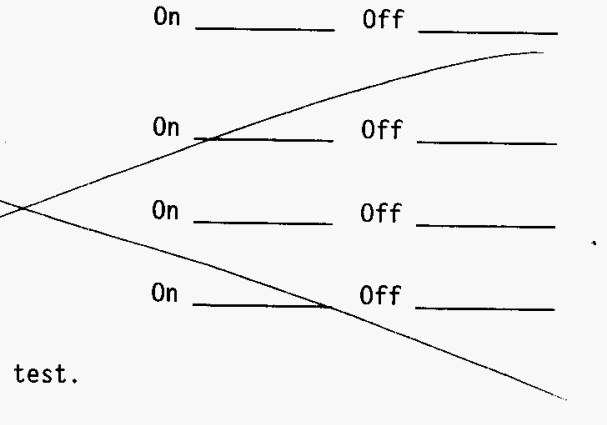

END OF TEST 


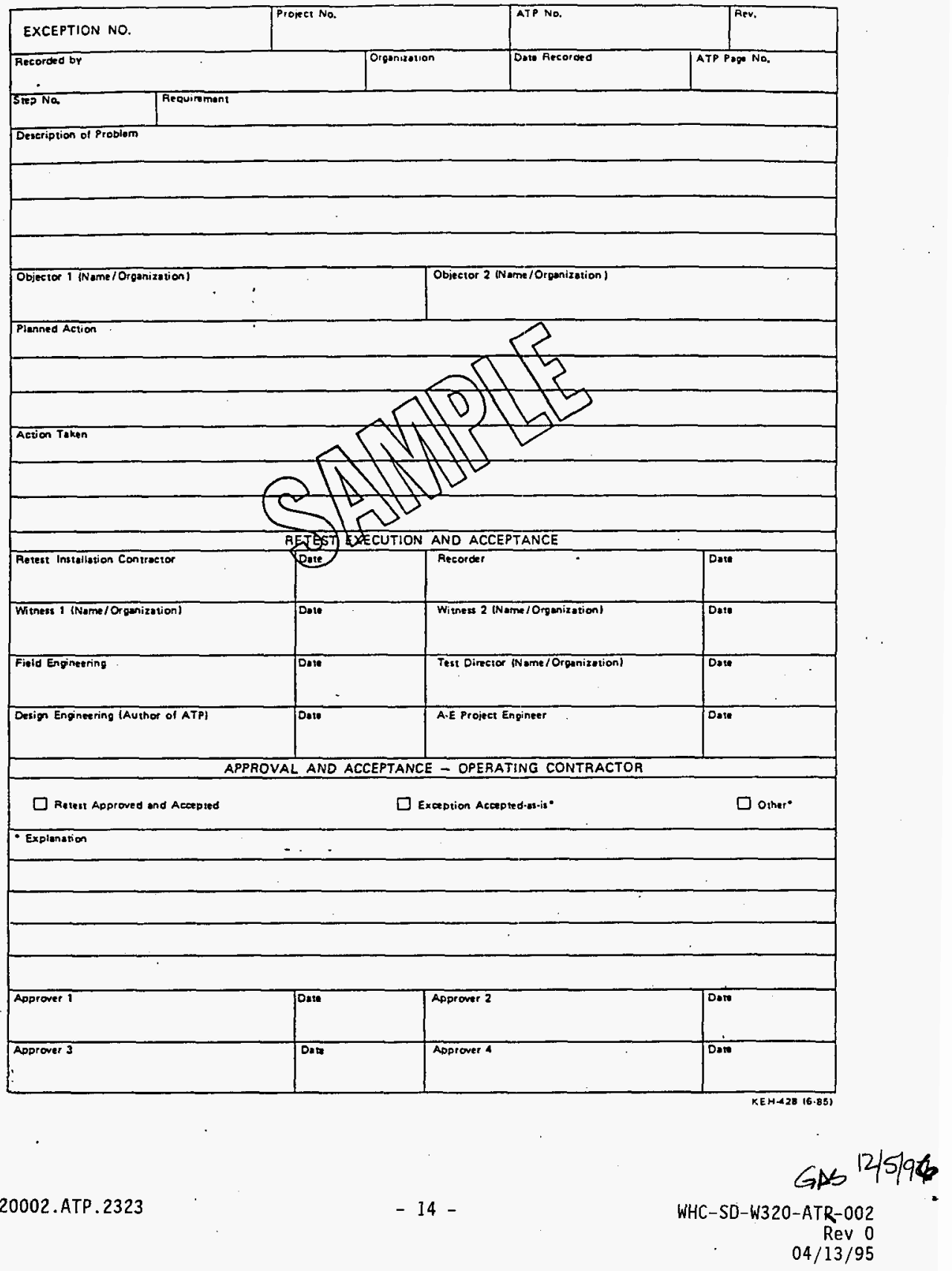

